\title{
A COMPARISON OF THE ENGLISH ACADEMIC RESULTS OF K16 NON- ENGLISH MAJOR STUDENTS BY DIFFERENT ETHNICITIES AND GENDER AT THAI NGUYEN UNIVERSITY OF SCIENCES
}

\author{
Nguyen Thi Thao \\ $T N U$ - University of Sciences
}

\begin{abstract}
English teaching and learning has become an essential strategy for the social development of Vietnam. However, the achievement in learning English depends on a lot of factors including the teaching methods, students' academic backgrounds and also students' attitudes towards the language learning. This study investigated whether or not gender and ethnicity factors impact on the academic result of university students from different ethnic groups. Also, this descriptive study attempts to compare the academic results of the three compulsory English courses in the university formal syllabus. The data is collected from 304 non-English major students from different ethnic groups of K16 at Thai Nguyen University of Sciences. Results indicated that gender played an important part in the academic achievement of those students. Besides, ethnic factors also partially impacted on the academic results of university students. The findings of the study are expected to be valuable sources for local teachers and researchers who want to investigate the reasons why gender affects the learning English, and the relationship between the students' identity and English learning outcomes.
\end{abstract}

Key words: academic results; ethnic groups; gender; K16 students; Thai Nguyen University of Sciences

Received: 13/4/2020; Revised: 04/6/2020; Published: 10/6/2020

\section{SO SÁNH KẾT QUẢ HỌC TẬP TIẾNG ANH THEO DÂN TỘC VÀ THEO GIỚI TÍNH CỦA SINH VIÊN KHÔNG CHUYÊN NGỮ K16 TRƯỜNG ĐẠI HỌC KHOA HỌC - ĐẠI HỌC THÁI NGUYÊN}

Nguyễn Thị Thảo

Truò̀ng Đai hoc Khoa hoc-ĐH Thái Nguyên

\section{TÓM TẮT}

Dạy và học tiếng Anh đang trở thành một chiến lược quan trọng cho sự phát triển xã hội tại Việt Nam. Tuy nhiên, thành tích học tập tiếng Anh phụ thuộc vào rất nhiều yếu tố bao gồm phương pháp giảng dạy, nền tảng kiến thức của sinh viên và cả thái độ của sinh viên đối với việc học ngôn ngữ. Nghiên cứu nhằm mục đích điều tra xem liệu các yếu tố giới và dân tộc có ảnh hưởng đến kết quả học tập của sinh viên đại học từ các nhóm dân tộc khác nhau hay không. Ngoài ra, nghiên cứu cũng so sánh kết quả học tập của ba môn tiếng Anh bắt buộc trong khung chương trình đại học. Dữ liệu được thu thập từ 304 sinh viên không chuyên ngữ thuộc các nhóm dân tộc khác nhau của K16, Trường Đại học Khoa học - Đại học Thái Nguyên. Kết quả chỉ ra rằng giới tính đóng một phần quan trọng trong thành tích học tập của các sinh viên này. Bên cạnh đó, yếu tố dân tộc cũng tác động một phần đến kết quả học tập của sinh viên đại học. Những phát hiện của nghiên cứu dự kiến sẽ là nguồn tham khảo có giá trị cho các giáo viên và nhà nghiên cứu địa phương trong việc tìm hiểu lý do tại sao giới ảnh hưởng đến việc học tiếng Anh và mối quan hệ giữa bản sắc riêng của sinh viên các dân tộc với kết quả học tập tiếng Anh của nhóm sinh viên này.

Từ khóa: kết quả học tập; dân tộc; giới tính; sinh viên K16; Truờng Đại học Khoa học - Đại học Thái Nguyên

Ngày nhận bài: 13/4/2020; Ngày hoàn thiện: 04/6/2020; Ngày đăng: 10/6/2020

Email:thaont@tnus.edu.vn

DOI: https://doi.org/10.34238/tnu-jst.2989

http://jst.tnu.edu.vn; Email: jst@tnu.edu.vn 


\section{Introduction}

English is considered as the international language which helps to foster the integration and bridge the gap among people from different communities in the world. Also, English is the language of sciences with millions of research papers and published articles written in English, and it is believed that "English will remain the primary language of research" [1]. As a result, many countries whose mother tongues are not English have invested for several decades much expense and effort into improving their English proficiency, and Vietnam is not an exception.

To equip young people with good English competence, English has been included in the training program as a compulsory subject from primary school to higher education in Vietnamese educational system for many years. In addition, English teachers have applied a lot of different teaching methods to enhance the quality of English education. However, it is still very challenging for Vietnamese students to have a good English competence because "acquiring or learning a language requires much time and effort" from both teachers and learners [2]. It is implied that the learner should contribute as much as he/she gains, and so learn in an interdependent way [3]. However, "the English learning environment in Vietnam is described as a cultural island where the teacher is expected to be the sole provider of experience in the target language" [4]. Thus, while teachers are considered as the controllers and knowledge providers, students are quite passive [4] - [6]. One of the reasons is that Vietnamese people are still greatly influenced by long cherished Confucianism [4], [7]. This style of teaching and learning may partially affects the English learning outcomes of university students, especially students from remote and mountainous areas with low socio-economic and academic backgrounds. Because of the fact that most of these students are from ethnic minority groups, they have had limited access to English, and some people even believe that it is not necessary for them to learn a foreign language when their national language is not fully mastered. Thus, the researcher hopes to investigate the factors related to ethnic characteristics and gender which can affect the English academic results of those students.

The above mentioned reasons have shaped the researcher's study in analyzing the effectiveness of the teaching and learning through comparing academic results of students from different ethnicities and gender.

The objectives of study are:

- To find out the current state of English learning of university students from different ethnic groups through English academic results at Thai Nguyen University of Sciences (TNUS)

- To identify the effect of ethnic and gender characteristics on the English learning of these student groups.

- To provide implications and suggestions to improve the quality of teaching and learning English for university students from different ethnicities and gender.

The study is therefore to serve as a reference source for researchers and English teachers who want to find out the reasons for gender's effect on the learning English of university students, and the relationship between the students' identity and English learning outcomes.

\section{Methodology}

The study used quantitative methods to find out how the students' English learning outcomes as measured by the test are related to their ethnicity and gender. Participants in the study were the university students in their second year of K16, TNUS. Of these students, 157 are male and 147 are female. They are of seven different ethnic groups (see Figure 1). Data were collected from their test scores in the 2019-2020 academic year. 


\section{Findings and Discussion}

\subsection{The students' profile}

\subsubsection{Age and gender distribution}

Results of the information gathered show that most of students in their second year at university are at the age of 20 and 21 . The gender contributes quite equally with 157 male students and 147 female students. However, gender distribution in each ethnic group is significantly different.

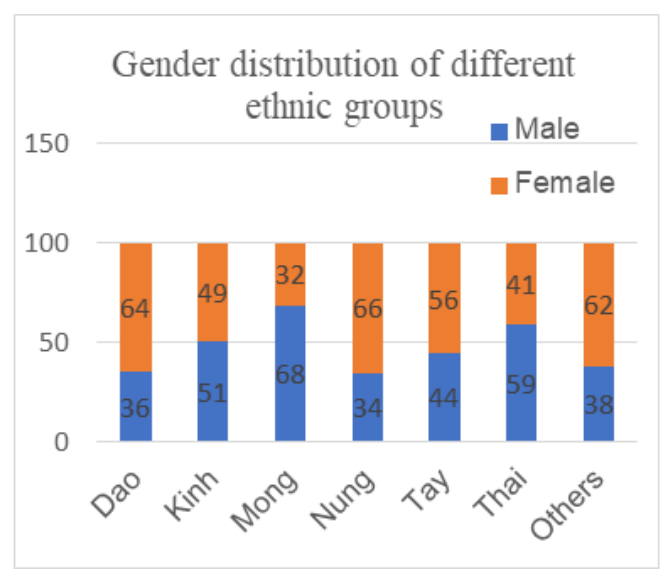

Figure 1. Gender distribution of different ethnic groups

Figure 1 illustrates the proportion of males and females from different ethnic groups who participated in university study of K16 at TNUS. Overall, it is clear that there were significant differences between the percentage of males and females in different ethnic groups joining the tertiary program. However, the proportion of males and females in Kinh ethnic group was quite equal.

Nung, Dao, Others and Tay groups had a much bigger proportion of females in the university program, taking 66\%, 64\% 62\% and $56 \%$ respectively, while males from Mong and Thai groups overtook females from these groups with the proportion of $68 \%$ and $59 \%$ in order.

\subsubsection{Ethnicity distribution}

The distribution of ethnicities of second year students in the school year of 2019-2020 is presented in figure 2. Obviously, TNUS witnessed a diversity of ethnic groups participating in the learning process to get a bachelor degree. The participants are from 17 different ethnic groups of the northern mountainous area of Vietnam. Especially, there is a relative equality between the number of students from Kinh considered as the dominant ethnic group of Vietnam accounting for $86 \%$ of the total national population and students from the Mong group, a minority ethnic group, with $29.1 \%$ and $25.8 \%$ of the total participants respectively. These two groups are the two major groups, which follows by Tay and Nung groups with $17.6 \%$ and $9.5 \%$ respectively. Besides, the proportions of students from the Thai group and from the Dao group are $5.6 \%$ and $4.6 \%$. The rest are from 11 different ethnic minority groups including Bo Y, Cao Lan, San Chi, San Diu, Si La, Muong, La Ha, Lao, Giay, Ha Nhi and Hoa, which counts for $7.2 \%$ of total students.

\section{Ethnicities of second year students}

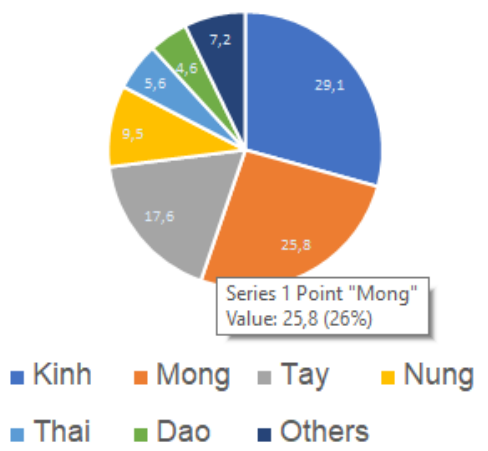

Figure 2. Distribution of ethnicities of second year students, school year of 2019-2020

3.2. The comparison of English average scores by different ethnic groups and gender

3.2.1. A comparison of the English scores by ethnic groups

With the aim of equipping students with good English proficiency, TNUS designs the English program including 3 different levels and requires students to follow the training program in order from level 1 to level 3 so 
that they can acquire the English competence to meet the need of the society after graduating from the university. The subject English 1 is designed for level 1, English 2 is representative of level 2 and English 3 is the subject for the highest level, level 3. In the first semester of year 1, students are required to learn English 1. In the second semester of year 1, they are planned to learn English 2, and English 3 are taught in the first semester of year 2. The English lecturers for the three subjects can be different, depending on the assignment from the academic training department. All the subjects focus on the four English skills which provide students with a range of vocabulary, pronunciation and grammar items so that they can be confident to communicate in English about basic daily topics. The three subjects consist of 10 learning credits ( 1 credit is equivalent to 15 teaching periods and 1 teaching period is 50 minutes), in which 4 credits is for English 1, 3 credits is for English 2 and English 3 also occupies 3 credits. The textbooks used for the three subjects are New English File elementary [8] and New English File preintermediate [9].

During English 1, students learn two third of the content of New English File elementary. The purpose of English 1 is to help students become more familiar with English language, provide them with very basic English knowledge of pronunciation (vowels and consonants), grammar (present simple and present continuous tenses, pronouns, adverbs of frequency and so on), vocabulary (numbers, jobs, family, houses, etc.) and English skills with easy daily topics such as saying time, and dates, making friends and talking about family.

English 2 covers the rest part of New English File elementary and one third of the content of New English File pre-intermediate. It equips students with basic knowledge about a range of grammar (present perfect, be going to, comparatives, quantifiers, relative clauses, etc.,) vocabulary (holiday, food, drinks, body, weather, personality, adventure) and phonetic topics (sentence stress, silent sounds, and so on) to help them consolidate and develop listening, speaking, reading and writing skills and effectively use the language input in everyday communication situations. This course also aims to help students practise and strengthen the skills and knowledge gained in English 1. At the end of the course, students are required to achieve the language ability necessary for their further study in English 3.

The rest of New English File pre-intermediate is taught in English 3. In this subject, students are supplied with the English knowledge of grammar on the perfect present tense, comparative structures, conditional sentences, reported speech, past perfect tense, vocabulary of clothes, animals, school, health, lifestyle; how to form words; adjectives, common verbs and pronunciation on vowel and consonant sounds, word stress and sentence stress. The four English skills are focused so that students can use and develop effectively the language in everyday communication situations. Especially, at the end of this module, students are required to gain the language ability necessary to meet the requirement of university's output standards equivalent to B1 level of Common European Framework of Reference (CEFR) and the need of the social communication.

There is a significant difference in the way of evaluating students between English 1 and English 2 and 3. Although $40 \%$ of the total score is spent for participation in class and mid-course test and $60 \%$ is for the final test, the formats of the final tests are completely different. In English 1, students are designed to take a multiple choice test on computer without writing, listening and speaking sections while in English 2 and English 3, they are required to take the final test with the four skills, in which each skill takes $25 \%$ of the total score. 
The average scores of the three English subjects that students got during the first and the second year at university are shown in Figure 3. Overall, there were slight differences among the average scores of different ethnic groups. However, it is also clear that Dao ethnic students got the highest English score compared with other ethnicities while students from the Thai ethnic group recorded the lowest one.

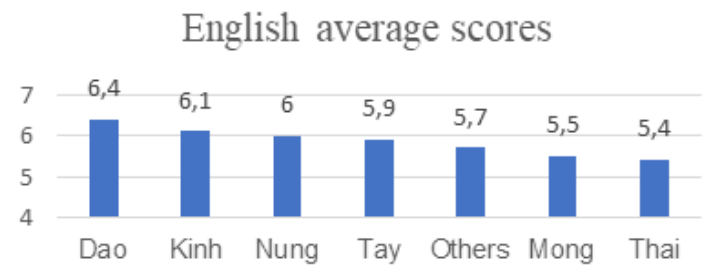

Figure 3. English average scores of ethnicities

Dao students scored the highest total, 6.4 points per 10, followed by Kinh students with 6.1 points. Nung and Tay were quite similar in terms of English academic achievement with 6 points and 5.9 points respectively. The figures for students from Mong and other ethnic groups were 5.5 points and 5.7 points in order. Interestingly, the Thai ethnic group stood at the lowest rank with 5.4 points, one score lower than that of Dao people.

\subsubsection{A result comparison of the three English} subjects by ethnicities

Figure 4 shows the academic scores of the three English subjects by ethnicities.

Interestingly, there is a slight decline in the English scores of the three subjects of all the student groups, in which English 1's result was the best, followed by English 2 and the worst one was English 3.

The score for English 1 varied from 5.7 to 6.6 points with the highest score belonging to Dao students. All the scores by different groups decreased in English 2, which fluctuated from 5.3 points to 6.5 points depending on the different ethnicities. Significantly, English 3 witnessed the worst performances by all the students with the scores of 4.8 to 6.0 per 10, much lower than the result of English 1.

\section{Scores of 3 English subjects by ethnicities}

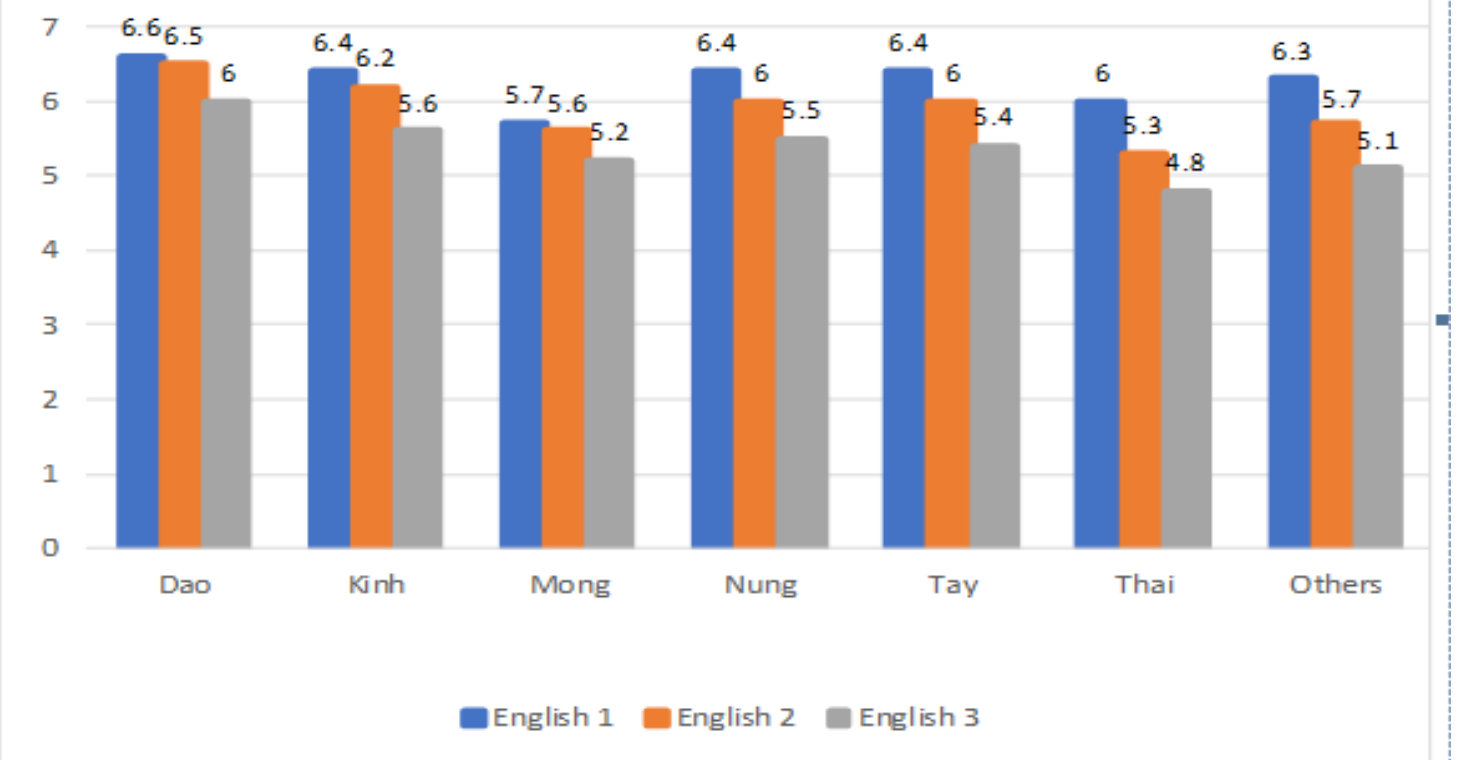

Figure 4. Scores of the three English subjects by ethnicities 
It is also necessary to point out that there was the most obvious decline in the academic results of Thai students with 6.0 points in English 1 dropping to 4.8 points in English 3 while the trend of Dao students showed the smallest change of all, with 6.6 for English 1, 6.5 for English 2 and 6.0 for English 3.

Obviously, the inequality in time distribution, testing format, testing content and the difficulty level in English subjects impacted greatly on the academic results of students. While English 1 is considered the basic subject with easier testing format, it lasts the longest, with 60 teaching periods. In contrast, English 3 is the most difficult one that covers a lot of English knowledge and requires the use of English in real context with the four-skill test for the final examination but lasts only 45 teaching periods. As a result, students had the best performance in English 1's result and English 3 was their most challenging subject.

\subsubsection{A comparison of the English scores by} gender

\subsubsection{The difference in the English average scores by gender}

Figure 5 shows the average academic result by male and female students of K16, TNUS. Male and female students had a quite big difference in academic results. The average score of English subjects by males was 5.5 points, 0.7 point lower than the score by female students.

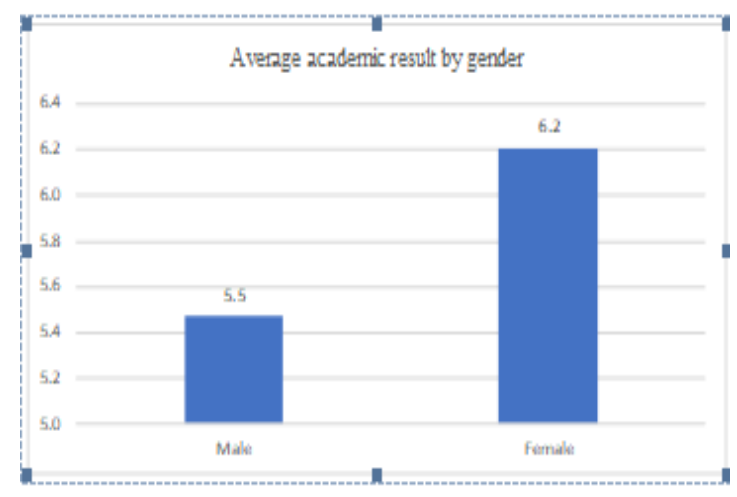

Figure 5. Average academic result by gender
3.2.3.2 The difference in the English scores of the three subjects by gender

Figure 6 compares the scores of the three English subjects by gender. Overall, female students showed their better proficiency with regard to all the English examinations. In English 1, the average score that females got was 6.5 points, 0.6 point higher than males' score. Similarly, 6.3 points and 5.8 points were their scores for English 2 and English 3, respectively, which is 0.8 point higher than male students' scores in both of the subjects.

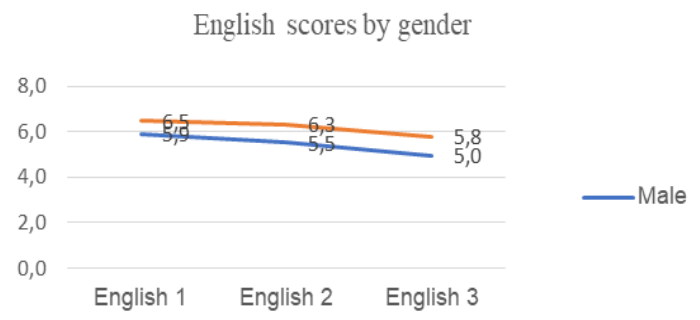

Figure 6. Scores of the three English subjects by gender

3.2.3.3 The difference in the English average score by gender in each ethnic group

Figure 7 compares the academic results of students from different ethnic groups by gender. Overall, female students showed a better ability in getting high scores than male students in almost every ethnic group, except for the Thai group. In addition, the Dao group witnessed the biggest gap in the English scores of males and females.

Females in most groups gained the average score of over 6.0 points, slightly higher than males who got the scores from 5.1 to 5.8 points depending on each ethnic group. However, in the Thai group, males and females' scores were quite similar with the score of 5.4 for males and 5.3 for females.

Also, Dao, Others, Kinh and Nung groups were the ones with a significant inequality between scores of male and female students, in which females of these groups achieved 2.1, 1.0, 0.9 and 0.7 point higher respectively than males. Finally, the Mong and Tay groups showed a less difference with 0.5 and 0.3 point gap between females and males' scores in order. 


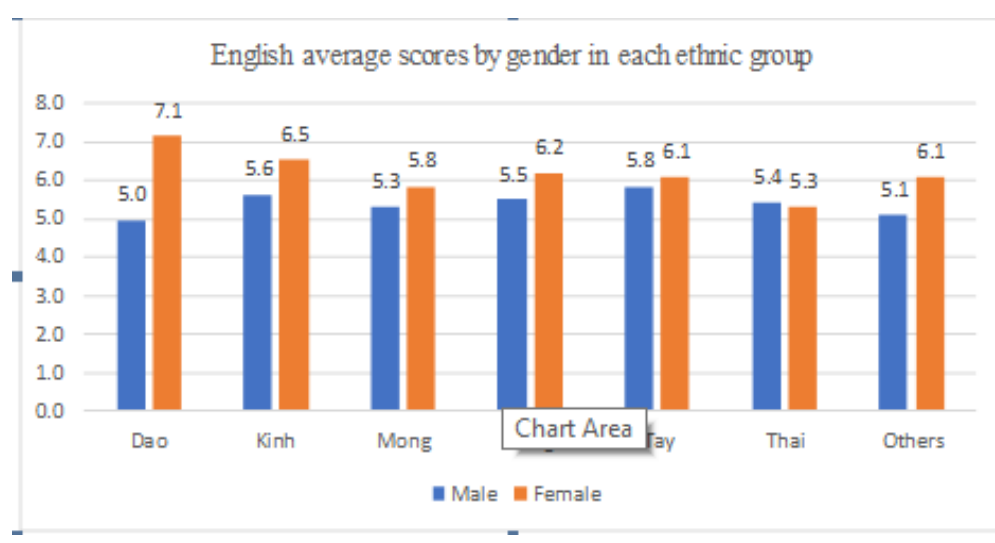

Figure 7. English average score by gender in each ethnic group

\subsection{Discussions}

It could be concluded that gender had more impact on the academic results of students from different ethnic groups, compared to the ethnicity factor; specifically, females showed a better capacity in mastering skills than males. This finding is consistent with recent research conducted by other researchers, whose studies revealed better performance of female students on tests measuring second/foreign language proficiency than male students [10] - [14].

Dao students demonstrated the best ability to learn English because the number of females greatly overtook the number of males. The similar explanation could be applied for Tay and Nung groups. In contrast, the proportion of male students in Mong was much bigger than the one of females, which lowered the average score of the whole group.

Among all the 7 ethnic groups, students from the Thai group had the lowest score with a very minor difference between males and females. This implies that the general current state of learning English in this group is worse than others. What are the main reasons for this should be investigated in later studies.

Students from the Kinh ethnic group, the majority ethnic group in Vietnam, have always been thought to be more dominant and competent in learning English, but this study showed that the academic achievement of Kinh male and female students is actually lower than that of Dao female students.
Further studies can be conducted in different contexts to compare with this result and then make any relevant conclusions.

\section{Conclusions and recommendations}

Based on the findings mentioned above, some conclusions and recommendations were drawn as follows:

English appeared to be considerably challenging to most of the student participants in this study. The average score of the three English subjects was 5.8 points out of 10 , as collected from 304 students in their second year. Therefore, the administrator and the English lecturers should work together and think of the reasons and solutions to improve this situation so that students can have a better achievement in terms of English learning.

With regard to the ability of learning English of ethnicities, Dao female students seemed to be the most potential with the highest scores in all the three subjects. In contrast, students from the Thai ethnic group showed the worst performance in the field of English learning with the lowest scores at all the three English subjects, compared with others. What could be the factors affecting their learning may be a good question for further studies.

With respect to the difficulties of the English subjects, English 3 was considered the most challenging with the lowest scores by students of all the ethnicities. The reasons could be related to the time for the subject, the format and the content of the final exam, the teaching methods and the requirement of the subject. 
Thus, a review of the English program should be needed, which could help to enhance in teaching and learning English at the university. In addition, gender also showed its pivotal effect on the difference in English learning achievement, in which females displayed much better achievement than males in all of the three subjects. Then, the English lecturers should also think of applying a kind of method that helps shorten the gap between each gender's learning or improves male students' academic results.

Finally, related to teaching students from different ethnic groups with different English knowledge backgrounds and living conditions, English lecturers should apply a variety of teaching methods which suit for students at all the English levels. If possible, the administrators and English lecturers can organize some extra English courses that aim to help weaker students to catch up with the university program.

\section{REFERENCES}

[1]. J. Swales, "Utilizing the literatures in teaching the research paper," TESOL Quarterly, vol. 21, no.1, pp. 41-68, March, 1987. [Online serial]. Available:

https://www.semanticscholar.org/paper/Utilizing -the-Literatures-in-Teaching-the-Research-

Swales/82f82303f529dc1ef8dafa00ecc5dfe5ab7 a562b. [Accessed February 2, 2020].

[2]. N.T. Hong, W. Warren and H. Fehring. "Factors affecting English language teaching and learning in higher education," English Language Teaching, vol. 7, no. 8, p.94, July, 2014, Canadian Center of Science and Education. [Online serial]. Available: https://files.eric.ed.gov/fulltext/EJ1076004.pdf. [Accessed February 10, 2020].

[3]. M. P. Breen and C. N. Candlin. "The essentials of a communicative curriculum in language teaching," Applied Linguistics, vol.1, no. 2, pp. 89-112, July, 1980. [Online serial]. Available: http://dx.doi.org/10.1093/applin/I.2.89. [Accessed February 2, 2020].

[4]. V. C. Le, "Language and Vietnamese pedagogical contexts," In Proceedings of The Fourth International Conference on Language and Development, Hanoi, Vietnam. October, 1999, pp. 13-15.

[5]. T. N. Nguyen and T. L. Ho, "The enhancement of learner autonomy and the growth of English language proficiency," Language In India, vol.12, no.4, p. 427, April, 2012. [Online serial]. Available:

https://www.academia.edu/27178532/The_Enha ncement_of_Learner_Autonomy_and_the_Grow th_of_English_Language_Proficiency.

[Accessed February 2, 2020].

[6]. T. T. Dang, "Learner Autonomy in EFL Studies in Vietnam: A Discussion from Sociocultural Perspective," English Language Teaching, vol 3, no.2, pp. 3-9, June, 2010. [Online serial]. Available:

https://pdfs.semanticscholar.org/6655/5101f23d 372d1e263607d71782a041bb9bdf.pdf. [Accessed February 2, 2020].

[7]. T. H. T. Pham, "The Development of the Higher Education Sector of Vietnam within the Globalization Discourse: Using Futures Methodologies," Journal of Futures Studies, vol.11, no. 2, pp.35-60, November, 2006. [Online serial]. Available: https://jfsdigital.org/articles-and-essays/2006-

2/vol-11-no-2-november/articles/thedevelopment-of-the-higher-education-sector-ofvietnam-within-the-globalization-discourseusing-futures-methodologies/. [Accessed February 20, 2020].

[8]. C. Oxenden, C. Latham-Koenig and P. Selegson, New English File elementary. Oxford University Press, 1996.

[9]. C. Oxenden, C. Latham-Koenig and P. Selegson, New English File pre-intermediate. Oxford University Press, 1997.

[10]. K. Field, "Why are girls better at modern foreign languages than boys?" in Modern foreign language teaching, K. Field (Ed.), London: Routledge, 2000, pp. 125-135.

[11]. M. Chavez, Gender in the language classroom. Boston, MA: McGraw-Hill, 2001.

[12]. J. Carr and A. Pauwels, Boys and foreign language learning: Real boys don't do languages. New York: Palgrave Macmillan, 2006.

[13]. B. Murphy, "Foreign language learning in Irish second level schools: Gender very much on the agenda," Irish Educational Studies, vol. 29, no. 1, pp. 81-95, 25 June, 2010. [Online]. Available: https://www.tandfonline.com/doi/full/10.1080/0 $\underline{3323310902884367 \text { ? scroll=top\&needAccess }=\mathrm{tr}}$ ue. [Accessed May 20, 2020].

[14]. D. Główka, "The impact of gender on attainment in learning English as a foreign language," Studies in Second Language Learning and Teaching, vol. 4, no.4, pp. 617635, 2014. [Online]. Available: https://files.eric.ed.gov/fulltext/EJ1135117.pdf. [Accessed May 20, 2020]. 